\title{
PENGARUH SALES PROMOTION, PRODUCT QUALITY, DAN HEDONIC BEHAVIOR PADA IMPULSE BUYING
}

\author{
Irma Septiana \\ Universitas Negeri Surabaya \\ irma.17080574053@mhs.unesa.ac.id \\ Widyastuti Widyastuti \\ Universitas Negeri Surabaya \\ widyastuti@unesa.ac.id
}

\begin{abstract}
A pandemic causes transactions in e-commerce to increase in health products. During the pandemic, impulsive purchases in e-commerce increased due to lockdown and fear of price increases. This research focuses on impulsive online purchases that are influenced by sales promotions, product quality, and hedonistic behavior. This type of research approach is quantitative with a causality research design. This analysis uses primary and secondary data sources. Data collection method using google form. Question measurement using a 5-point Likert scale. The population is infinite, and the number of samples collected is 197, which corresponds to the characteristics of the respondents is 123 respondents - the statistical analysis using multiple linear regression. The research results state that of the three independent variables, the hedonic behavioural variable significantly affects consumers' impulsive purchases of health products in e-commerce. Other variables, namely sales promotion and product quality, has no significant effect on impulsive purchases.
\end{abstract}

Keywords: e-commerce; hedonic behavior; online impulse buying; product quality; sales promotion

\section{PENDAHULUAN}

Pandemi Covid-19 telah memengaruhi semua aspek kehidupan, salah satunya aspek perdagangan (Kompas.com, 2020b). Pandemi menyebabkan segala aktivitas yang dilakukan secara langsung, bertransformasi menjadi serba online. Dalam hal ini, e-commerce merupakan salah satu pemanfaatan teknologi pada sistem perdagangan selama pandemi. E-commerce adalah tempat berjual atau membeli suatu produk dengan menggunakan bantuan internet (Wikipedia.com, 2020). Adanya peraturan pembatasan sosial, menyebabkan transaksi dengan media e-commerce mengalami peningkatan. Jumlah transaksi di tahun 2020 mengalami peningkatan sebesar 60 juta transaksi (CNNIndonesia.com, 2020). Hal ini dapat terjadi karena, adanya perubahan sistem pengeluaran dan pembayaran masyarakat di tengah pandemi untuk memenuhi kebutuhan sehari-hari.

Tingginya perkembangan e-commerce di Indonesia, menyebabkan adanya persaingan untuk memerebutkan pasar konsumen. Di Indonesia terdapat lima e-commerce dengan transaksi tertinggi berdasarkan data survey iprice.co.id, yaitu Shopee, Tokopedia, Bukalapak, Lazada, dan Blibli (Iprice.co.id., 2020). Namun, selama pandemi yang seharusnya transaksi di e-commerce meningkat terdapat tiga e-commerce di tingkat lima besar yang mengalami penurunan dalam penggunaan transaksinya di tahun 2020. Ketiga e-commerce tersebut adalah Tokopedia, Bukalapak, dan Lazada (Databoks.com, 2020b).

Kebutuhan sehari-hari masyarakat selama pandemi mengalami perubahan (Jawapos.com, 2020). Data Badan Pusat Statistik (BPS), terdapat tiga kategori produk yang paling dicari selama pandemi, yaitu bahan makanan, produk kesehatan, dan pulsa atau paket data. Beberapa produk bahan makanan yang dimaksudkan seperti teh, susu, madu, dan produk sembako lainnya (Databoks.com, 2020a). Kategori produk kesehatan seperti masker, hand sanitizer, face shield, disinfektan, tisu, dan air purifier (Beritasatu.com, 2020). Sedangkan kategori produk pulsa atau paket data meningkat dikarenakan adanya aktivitas work from home (WFH) dan pembelajaran daring (Databoks.com, 2020a). 
Irma Septiana \& Widyastuti Widyastuti. Pengaruh Sales Promotion, Product Quality, dan Hedonic Behavior pada Impulse Buying

Selama pandemi perilaku konsumen dalam berbelanja di e-commerce juga mengalami perubahan, hal tersebut dikarenakan adanya work from home (WFH) (Kompas.com, 2020a). Realitanya dalam melakukan pembelian secara online konsumen cenderung bertindak secara irasional dan tidak logis (Yiğit, 2020). Hal tersebut menyebabkan terjadinya pembelian impulsif. Pembelian impulsif secara online merupakan pembelian secara langsung tanpa ada niatan atau tidak direncanakan sebelumnya melalui media online (A.K \& M.G.S, 2016). Pembelian impulsif secara online di masa pandemi mengalami peningkatan disebabkan adanya lockdown, kecenderungan untuk membeli barang ekstra karena harus di rumah, serta rasa takut akan kenaikan harga dan virus (Naeem, 2020).

Pembelian impulsif dikategorikan menjadi empat jenis, yaitu impulse murni, impulse terencana, reminder impulse, dan suggestion impulse (Lo et al., 2016). Selama pandemi konsumen yang melakukan pembelian impulsif disebabkan oleh suatu rangsangan stimulus. Terkadang konsumen juga akan secara tidak sengaja teringat untuk membeli suatu produk yang dibutuhkan selama pandemi. Dalam hal ini, pada jenis reminder impulse dan suggestion impulse sesuai untuk jenis pembelian impulsif yang terjadi selama pandemi. Konsumen bisa saja teringat untuk melakukan pembelian akan produk tersebut dan adanya rangsangan stimulus yang menyebabkan konsumen melakukan pembelian pada produk tersebut secara impulsif (Xu \& Huang, 2014).

Salah satu kunci untuk mendorong pembelian impulsif konsumen di tengah pandemi, yaitu sales promotion (Xu \& Huang, 2014). Bentuk sales promotion yang dilakukan untuk meningkatkan pembelian impulsif pada konsumen diantaranya diskon, sampel gratis, skema beli satu dapat gratis satu, dan program loyalitas (A.K \& M.G.S, 2016). Promosi penjualan mempunyai dampak terhadap pembelian pada konsumen (Tamilselvi, 2019). Promosi penjualan akan memicu ingatan atau memori implisit konsumen yang dapat memengaruhi pembelian impulsif konsumen (Hultén \& Vanyushyn, 2014). Penelitian Hulten dan Vanyushyn, menunjukkan promosi penjualan berpengaruh signifikan pada pembelian yang tidak direncanakan (Hultén \& Vanyushyn, 2014). Tetapi Kurniawati dan Restuti menyatakan bahwa promosi penjualan tidak berpengaruh signifikan terhadap pembelian impulsif (Kurniawati \& Restuti, 2014).

Salah satu nilai yang dihendaki konsumen kepada produsen, yaitu kualitas akan produk dan jasa yang tinggi (Indra Wiguna \& Nurcaya, 2014). Kualitas produk yang baik memiliki dampak pada kepuasan atau kesenangan konsumen sehingga, akan memicu untuk melakukan pembelian yang tidak direncanakan (Yeboah \& Owusu-Prempeh, 2017). Dengan demikian, dorongan untuk melakukan pembelian yang tidak direncanakan akan tinggi apabila, produk yang dihasilkan juga memiliki kualitas yang tinggi. Product quality memiliki pengaruh signifikan terhadap pembelian yang tidak direncanakan (Angela \& Paramita, 2020). Penelitian Husnul et al. (2017) dan Maulana (2020) menunjukkan pembelian impulsif konsumen tidak dipengaruhi oleh kualitas produk

Motivasi hedonis yang muncul dari pengalaman pelanggan saat berbelanja online, menjadi salah satu faktor terjadinya pembelian impulsif (Widagdo \& Roz, 2021). Banyak faktor yang dapat memengaruhi hedonisme, salah satunya ialah motif hedonik (Anggreani \& Suciarto, 2020). Menurut Solomon motif yang dimaksud, yaitu berbagi kepentingan bersama, pengalaman sosial, interaksi antar pribadi, status instan, dan the thrill of the hunt (Solomon, Marshall, and Stuart, 2008). Nilai belanja hedonis mengacu pada rasa senang yang diterima konsumen dari aktivitas pengalaman berbelanja online. Perilaku hedonis berpengaruh signifikan terhadap pembelian impulsif (Sri \& Asnawati, 2018). Sebaliknya, perilaku hedonik mempunyai pengaruh signifikan yang lemah terhadap impulse buying secara online (Darma \& Japarianto, 2014).

Berdasarkan penjelasan fenomena yang terjadi serta adanya kesenjangan dari penelitian terdahulu maka, tuuan penelitian ini untuk menganalisis dampak promosi penjualan, kualitas produk, dan perilaku hedonis terhadap pembelian impulsif. Studi dilakukan pada konsumen yang menggunakan salah satu e-commerce Tokopedia, Bukalapak, dan Lazada yang pernah melakukan pembelian impulsif pada jenis produk kesehatan seperti masker, hand sanitizer, face shield, disinfektan, tisu, dan air purifier yang meningkat pesat selama pandemi. 


\section{KAJIAN PUSTAKA DAN PENGEMBANGAN HIPOTESIS}

\section{Impulse Buying}

Perilaku konsumen dalam melakukan pembelian cenderung bertindak secara tidak logis sehingga, terjadilah pembelian impulsif (Yiğit, 2020). Impulse buying merupakan suatu tindakan pembelian yang sebelumnya secara sadar tidak direncanakan (Mowen, 2002). Adapun tiga faktor yang dapat memengaruhi pembelian impulsif secara online menurut Naeem (2020) yang pertama, yaitu atribut produk contohnya seperti karakteristik pada harganya dan kualitas produk. Faktor kedua, yaitu pemasaran yang membangun rangsangan stimulus kepada konsumen contohnya seperti iklan. Faktor ketiga, yaitu karakteristik dan sumber daya yang dimiliki oleh konsumen tersebut misalnya seperti kepribadian, waktu, dan uang. Indikator impulse buying pada penelitian ini dikutip dari Anggreani \& Suciarto (2020) dan Sri \& Asnawati (2020), yaitu spontanitas, kesenangan, dan membeli tanpa berpikir panjang konsekuensinya.

\section{Sales Promotion}

Salah satu strategi stimulus agar konsumen melakukan pembelian adalah dengan melakukan sales promotion (Xu \& Huang, 2014). Sales promotion merupakan suatu rangsangan stimulus yang didapat secara langsung oleh konsumen agar segera melakukan pembelian (Peter, 2014). Secara umum pada promosi penjualan terdapat tiga kategori utama, yaitu promosi konsumen (consumer promotion), promosi dagang (trade promotion), dan promosi wiraniaga (salesforce promotion) (Tjiptono, 2012). Pada penelitian ini indikator sales promotion yang digunakan diadaptasi dari Akram et al. (2018) dan Lo et al. (2016), yaitu coupons, rabate, dan markdown.

\section{Product Quality}

Nilai yang diinginkan konsumen kepada produsen yaitu kualitas akan produk yang tinggi (Indra Wiguna \& Nurcaya, 2014). Kualitas produk yang baik akan memiliki dampak pada kepuasan konsumen sehingga, akan memicu konsumen untuk melakukan pembelian (Yeboah \& OwusuPrempeh, 2017). American Society for Quality Control dalam buku Kotler, Philip (2004), mendefinisikan kualitas produk dengan suatu kelengkapan dan keunikan dari produk atau layanan yang dapat memengaruhi kinerjanya untuk dapat memuaskan kebutuhan konsumen. Pada penelitian ini indikator kualitas produk yang digunakan diadaptasi dari Husnul et al. (2017) dan Hikmah, (2020), yaitu kinerja (performance), daya tahan (durability), kesesuaian dengan spesifikasi (conformance to specifications).

\section{Hedonic Behavior}

Burhanuddin Salam (1997) mendefinisikan hedonisme dengan suatu hal akan dianggap baik, sesuai dengan kesenangan yang didatangkannya. Nilai belanja hedonis merujuk pada rasa senang yang diterima dari semua pengalaman aktivitas berbelanja (Sri \& Asnawati, 2018). Salah satu faktor yang memengaruhi hedonis, yaitu motif hedonik (Anggreani \& Suciarto A., 2020). Motif yang dimaksud dalam motif hedonik menurut Solomon, yaitu sharing of common interest, the thrill of the hunt, pengalaman sosial, status instan, dan interpersonal atraction (Solomon, M.C., Marshall. G.W., and Stuart, 2008). Indikator perilaku hedonis mengacu pada Widagdo \& Roz (2021) dan Sri \& Asnawati (2018), yaitu adventure shopping, gratification or relaxation shopping, dan idea shopping.

\section{Hubungan antar Variabel}

Promosi penjualan memiliki dampak terhadap pembelian yang dilakukan konsumen (Tamilselvi, 2019). Promosi penjualan akan dapat memicu ingatan atau memori implisit pada konsumen sehingga, dapat memengaruhi pembelian impulsif konsumen (Hultén \& Vanyushyn, 2014). Sales promotion pada e-commerce merupakan bentuk strategi promosi yang dikeluarkan oleh pihak e-commerce untuk menarik konsumen agar mau untuk bertransaksi di e-commerce tersebut. Dalam promosi penjualan di e-commerce jika dapat dilakukan lebih sering dan dilaksanakan dengan tepat maka, akan dapat meningkatkan pembelian impulsif pada konsumen di e-commerce tersebut (Zahara, 2019).

H1 : Sales promotion berpengaruh signifikan terhadap impulse buying pada pengguna e-commerce. 
Irma Septiana \& Widyastuti Widyastuti. Pengaruh Sales Promotion, Product Quality, dan Hedonic Behavior pada Impulse Buying

Serangkaian fungsi seperti ketahanan, ketepatan, dan kemudahan dalam penggunannya merupakan suatu kemampuan yang dihasilkan dari kualitas produk yang dijual di e-commerce. Kualitas produk yang tinggi memiliki dampak pada kepuasan konsumen sehingga, akan dapat memicu untuk melakukan pembelian yang tidak direncanakan pada konsumen (Yeboah \& Owusu-Prempeh, 2017). Dengan demikian, semakin meningkatnya kualitas produk tersebut maka, keputusan pembelian impulsif pada produk tersebut juga akan semakin tinggi (Indra Wiguna \& Nurcaya, 2014).

$\mathrm{H} 2$ : Product quality berpengaruh signifikan terhadap impulse buying pada pengguna e-commerce.

Meningkatnya pembelian yang tidak direncanakan dapat dipicu dengan adanya kesenangan secara positif (Hashmi et al., 2020). Big five invetory dari John (1990) yang kemudian diadaptasi oleh Ramdhani (2012) mengemukakan bahwa salah satu karakteristik dalam gaya hidup hedonis, yaitu cenderung implusif. Perilaku hedonisme dalam berbelanja di e-commerce merupakan bentuk dari perilaku konsumen yang melakukan pembelian di e-commerce untuk mewujudkan kesenangan. Adanya perilaku hedonik akan meningkatkan kemungkinan terjadinya pembelian secara impulsif (Anggreani \& Suciarto A., 2020).

$\mathrm{H} 3$ : Hedonic behavior berpengaruh signifikan terhadap impulse buying pada pengguna e-commerce.

\section{METODE PENELITIAN}

Penelitian ini menggunakan jenis pendekatan kuantitatif dan desain penelitian kausalitas yang menguji suatu hubungan sebab akibat antara variabel sales promotion, product quality, hedonic behavior dengan impulse buying. Sumber data yang digunakan adalah sumber data primer dan sekunder. Data primer dikumpulkan secara langsung dengan menggunakan angket, sedangkan untuk data sekunder berasal dari artikel terdahulu dan buku. Teknik pengumpulan data menggunakan angket yang disebarkan kepada pengguna e-commerce Tokopedia, Bukalapak, dan Lazada melalui google form. Pengukuran pertanyaan penelitian menggunakan skala likert 5 poin (Malhotra, N.K., \& Dash, 2016). Populasinya bersifat infinite karena, dalam penelitian ini tidak dapat menentukan jumlah populasi yang sesuai dengan karakteristik. Jumlah sampel yang terkumpul ada 197 sampel dan yang sesuai dengan karakteristik responden, yaitu 123 responden untuk dianalisis lebih lanjut. Teknik analisis data menggunakan analisis regresi linear berganda. Adapun model penelitian pada gambar 1 .

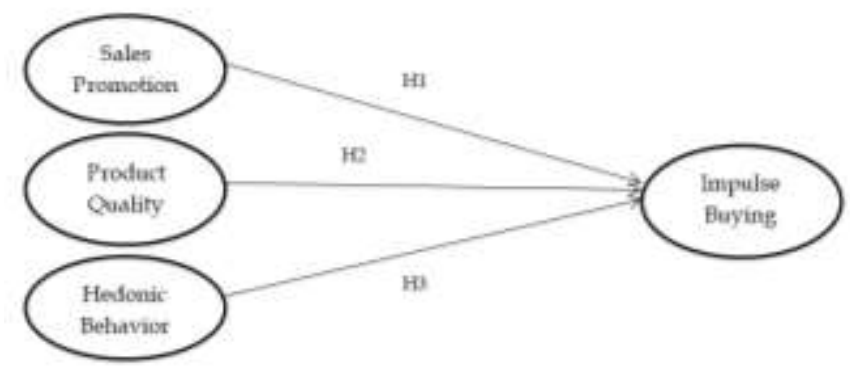

Sumber: Diolah peneliti

Gambar 1. MODEL PENELITIAN

\section{HASIL DAN PEMBAHASAN}

\section{Karakteristik Responden}

Total responden yang terkumpul berjumlah 197 responden, seluruhnya memenuhi karakteristik pertama, yaitu sebagai pengguna salah satu e-commerce Tokopedia, Bukalapak, dan Lazada. Pada karakteristik responden kedua, yaitu pernah melakukan pembelian secara spontan pada produk kesehatan di masa pandemi dan melanjutkan untuk menjawab angket berjumlah 123 responden. Dari jawaban 123 responden, diketahui hasil analisis deskriptif yang berisi kriteria sampel jenis kelamin, didominasi oleh responden dengan gender perempuan sebanyak 80 responden. Dari kriteria sampel 
umur, didominasi oleh responden dengan umur 18-25 tahun sebanyak 46 responden. Responden didominasi oleh mahasiswa sebanyak 47 responden. Kriteria sampel pada jumlah transaksi selama 4 bulan terakhir, didominasi dengan transaksi 3-5 kali sebanyak 62 responden.

Uji Validitas dan Reliabilitas

Tabel 1.

HASIL UJI VALIDITAS DAN RELIABILITAS

\begin{tabular}{|c|c|c|c|}
\hline Variabel & $\mathbf{r}$ hitung & $\mathbf{r}$ tabel & Keterangan \\
\hline Sales Promotion [cronbach's alpha: 0,779 ] & & \multirow{6}{*}{0,176} & Reliabel \\
\hline Voucher gratis ongkir menarik & 0,776 & & Valid \\
\hline Voucher potongan ongkir beragam nominalnya & 0,690 & & Valid \\
\hline Potongan harga yang diberikan menarik & 0,630 & & Valid \\
\hline Penurunan harga sangat menarik & 0,725 & & Valid \\
\hline Product Quality [cronbach's alpha: 0,790] & & & Reliabel \\
\hline Produk memiliki manfaat yang sesuai saat dipakai & 0,648 & \multirow{5}{*}{0,176} & Valid \\
\hline Produk memiliki tanggal kadaluarsa lama & 0,721 & & Valid \\
\hline Kemasan produk baik sehingga tahan lama & 0,691 & & Valid \\
\hline Produk memiliki manfaat sesuai standar & 0,632 & & Valid \\
\hline Produk bermanfaat dalam menjaga tubuh & 0,708 & & Valid \\
\hline Hedonic Behavior [cronbach's alpha : 0,735] & & \multirow{5}{*}{0,176} & Reliabel \\
\hline Penasaran akan produk yang ditawarkan & 0,621 & & Valid \\
\hline Berbelanja untuk memperbaiki suasana hati & 0,820 & & Valid \\
\hline Berbelanja untuk mengikuti mode terbaru & 0,863 & & Valid \\
\hline Impulse Buying [cronbach's alpha: 0,770] & & & Reliabel \\
\hline Terpicu untuk membeli langsung di e-commerce & 0,707 & \multirow{4}{*}{0,176} & Valid \\
\hline Senang berbelanja produk di e-commerce & 0,591 & & Valid \\
\hline Berbelanja tanpa berpikir panjang & 0,843 & & Valid \\
\hline Tetap membeli produk bermanfaat biarpun tidak butuh & 0,808 & & Valid \\
\hline
\end{tabular}

Sumber: Data SPSS diolah

Pada uji validitas, item akan dinyatakan valid jika, $r$ hitung $>r$ tabel dan uji reliabilitas, kuesioner penelitian akan dikatakan reliabel jika nilai pada cronbach's alpha > 0,6 (Sujianto, 2009). Berdasarkan tabel 1, semua item pertanyaan valid dan reliabel.

\section{Uji Asumsi Klasik}

Uji asumsi klasik yang digunakan, yaitu uji normalitas, uji multikolonieritas, dan uji heteroskedastisitas. Hasil uji normalitas dengan kolmogorov-smirnov jika, nilai sig >0,05 maka, data berdistribusi normal (Sujianto, 2009). Dari hasil uji, nilai signifikansi sebesar 0,992, bahwa data berdistribusi normal. Pada uji multikolonieritas jika, nilai tolerance $>0,1$ dan VIF $<10$ maka, tidak ada multikolinieritas pada variabel independen (Janie, 2012). Dari hasil uji yang dilakukan, diketahui nilai tolerance pada variabel sales promotion sebesar 0,512 nilai VIF 1,954 , nilai tolerance product quality sebesar 0,532 nilai VIF 1,879, dan nilai tolerance hedonic behavior sebesar 0,745 nilai VIF 1,343. Dari nilai tersebut, tidak ada gejala multikolinieritas. Uji heteroskedastisitas menggunakan glejser jika, nilai sig > 0,05 tidak terjadi gejala heterokedastisitas (Janie, 2012). Hasil pengujian, nilai sig variabel sales promotion sebesar 0,618 , nilai sig variabel product quality sebesar 0,078 dan nilai sig variabel hedonic behavior sebesar 0,065. Artinya tidak terjadi gejala heteroskedastisitas

\section{Uji Hipotesis}

Kriteria uji hipotesis, yaitu uji $t$ dan koefisien determinasi. Pada uji $t$ apabila, nilai signifikansi $<0,05$ maka hipotesis diterima (Janie, 2012). Tabel 2 nilai signifikansi variabel sales promotion sebesar 
Irma Septiana \& Widyastuti Widyastuti. Pengaruh Sales Promotion, Product Quality, dan Hedonic Behavior pada Impulse Buying

0,851, artinya H1 ditolak. Nilai variabel product quality sebesar 0,313, maka H2 ditolak. Nilai variabel hedonic behavior sebesar 0,000, $\mathrm{H} 3$ diterima.

Tabel 2.

UJI T

\begin{tabular}{lcccc}
\hline \multicolumn{1}{c}{ Varibel } & $\begin{array}{c}\text { Coefficients } \\
\text { Std. Error }\end{array}$ & $\begin{array}{c}\text { Coefficients } \\
\text { Beta }\end{array}$ & $\mathbf{t}$ & Sig. \\
\hline Sales Promotion &, 105 &, 015 &, 188 &, 851 \\
Product Quality &, 090 &, 078 & 1,014 &, 313 \\
Hedonic Behavior &, 084 &, 743 & 11,391 &, 000 \\
\hline Sunt
\end{tabular}

Sumber: Data SPSS

Tabel 3, proporsi variabel sales promotion, product quality, dan hedonic behavior terhadap impulse buying dilihat dari nilai $R$ square. Pengaruh ketiga variabel tersebut terhadap impulse buying sebesar $62,3 \%$ dan $37,7 \%$ sisanya dipengaruhi oleh variabel lain.

Tabel 3.

KOEFISIEN DETERMINASI

\begin{tabular}{cccc}
\hline $\mathbf{R}$ & $\mathbf{R}$ Square & $\begin{array}{c}\text { Adjusted } \mathbf{R} \\
\text { Square }\end{array}$ & $\begin{array}{c}\text { Std. Error of the } \\
\text { Estimate }\end{array}$ \\
\hline, $789^{\mathrm{a}}$ &, 623 &, 613 & 1,54519 \\
\hline
\end{tabular}

Sumber: Data SPSS

\section{Pengaruh Sales Promotion terhadap Impulse Buying}

Hasil riset ini, sales promotion tidak berpengaruh siginifikan pada pembelian impulsif. Adanya sales promotion, seperti voucher potongan ongkos kirim, penurunan harga, dan diskon pada produk kesehatan yang dijual di masa pandemi tidak memberikan dampak pada pembelian impulsif konsumen di e-commerce. Hasil ini sesuai dengan Kurniawati \& Restuti (2014), promosi penjualan tidak memiliki pengaruh signifikan terhadap impulse buying. Berdasarkan hasil dari jawaban responden, mereka akan tetap melakukan pembelian impulsif pada produk kesehatan karena faktor kebutuhan bukan karena responden akan terpengaruh dengan adanya diskon, penurunan harga ataupun voucher potongan ongkos kirim. Hal tersebut terjadi karena, responden menjadi lebih memprioritaskan untuk menjaga dan melindungi diri sendiri serta keluarga dari wabah covid-19. Hal tersebut sesuai dengan penjelasan Naeem (2020) bahwa pembelian impulsif secara online di masa pandemi meningkat disebabkan adanya lockdown, kecenderungan untuk membeli barang ekstra karena harus di rumah, serta rasa takut akan kenaikan harga dan virus. Selama pandemi responden akan merasakan adanya risiko yang tinggi serta kecemasan akan kehabisan stok produk kesehatan sehingga, responden akan tetap melakukan pembelian impulsif tanpa adanya stimulus dari promosi penjualan. Alasan lainnya, dari sebagian besar responden yang mengisi angket adalah orang yang sudah bekerja atau berumah tangga sehingga pembelian impulsif konsumen pada produk kesehatan tidak akan terpengaruh oleh voucher potongan ongkos kirim, penurunan harga, dan diskon karena, konsumen sudah memiliki penghasilan dan tingkat kepedulian terhadap kesehatan juga tinggi untuk melindungi keluarga.

\section{Pengaruh Product Quality terhadap Impulse Buying}

Product quality tidak berpengaruh siginifikan pada pembelian impulsif. Adanya kualitas produk yang baik pada produk kesehatan yang dijual di masa pandemi tidak memberikan dampak pada pembelian yang tidak direncanakan oleh konsumen di e-commerce. Hasil ini mendukung Maulana (2020) dan Husnul et al. (2017), bahwa product quality tidak memiliki pengaruh signifikan terhadap pembelian impulsif secara online. Alasan yang menyebabkan hal tersebut terjadi karena, pembelian produk kesehatan secara online menyebabkan konsumen tidak bisa mengetahui kualitas produk tersebut sehingga, konsumen pada usia muda, yaitu 18-35 tahun hanya akan melihat dari penilaian konsumen lain saat melakukan pembelian impulsif. Berbeda dengan konsumen usia tua yang tidak akan melihat 
penilaian konsumen lain, melainkan hanya perlu melihat gambar yang menurut konsumen bagus dan langsung melakukan pembelian impulsif. Selain hal tersebut, selama pandemi responden dihadapkan pada situasi yang membuat khawatir. Perasaan khawatir yang menyebabkan responden menjadi tertekan sehingga kehilangan kendali dalam berbelanja produk kesehatan. Adanya tekanan dan keinginan kuat untuk dapat terhindar dari wabah covid-19 menyebabkan peningkatan pembelian impulsif pada produk kesehatan di e-commerce. Responden akan melakukan pembelian impulsif pada produk kesehatan yang dijual di e-commerce karena, ingin melindungi diri dari virus dan takut akan kehabisan stok. Hal ini sesuai dengan penjelasan Naeem (2020) bahwa pembelian impulsif secara online di masa pandemi meningkat dikarenakan adanya kecenderungan untuk membeli barang ekstra, serta rasa takut akan kenaikan harga dan virus. Alasan lainnya juga karena, di masa pandemi bagi responden produk kesehatan seperti masker dan hand sanitizer menjadi kebutuhan dasar untuk dipenuhi demi melindungi diri dari wabah covid-19 sehingga, responden tidak akan memertimbangkan kualitas maupun merek ketika akan membeli produk tersebut.

\section{Pengaruh Hedonic Behavior terhadap Impulse Buying}

Hasil riset hedonic behavior berpengaruh siginifikan terhadap pembelian impulsif. Perilaku hedonis konsumen di masa pandemi dapat memberikan dampak pada pembelian yang tidak direncanakan akan produk kesehatan di e-commerce. Hal ini sesuai dengan fakta bahwa perilaku hedonis konsumen dalam berbelanja dapat memicu pembelian impulsif. Hasil tersebut sama dengan Ramdhani (2012), tentang teori big five invetory dari John (1990) yang sudah diadaptasi bahwa salah satu karakteristik gaya hidup hedonis yaitu cenderung implusif. Yiğit (2020) juga menjelaskan bahwa nilai belanja hedonis dapat mendorong konsumen untuk melakukan pembelian secara tiba-tiba dan tidak terencana. Hasil riset ini sejalan dengan Sri \& Asnawati (2018) bahwa perilaku hedonis berpengaruh signifikan terhadap pembelian impulsif. Dari keseluruhan responden dalam penelitian ini akan mengutamakan pembelian impulsif pada produk kesehatan karena, adanya kesadaran untuk lebih memprioritaskan kesehatan diri. Terlebih konsumen akan merasa senang jika, diri sendiri beserta keluarga dapat terlindungi dari wabah covid-19. Pengalaman konsumen dari berbelanja produk kesehatan di $e$ commerce pada masa pandemi akan membawa dampak kesenangan pada konsumen, hal tersebut dikarenakan adanya PSBB sehingga, konsumen sulit untuk berbelanja secara langsung. Nilai belanja hedonis merujuk pada rasa bahagia yang diterima konsumen dari aktivitas pengalaman berbelanja online (Sri \& Asnawati, 2018). Perilaku hedonis responden pada produk kesehatan terjadi karena, terciptanya suatu gairah belanja yang terpengaruh oleh adanya rasa khawatir dengan wabah covid-19. Dalam hal ini, dengan adanya perilaku hedonisme menyebabkan peningkatan pembelian impulsif pada produk kesehatan dikarenakan, responden akan menjadi bahagia dan aman jika kebutuhannya selama pandemi terpenuhi khususnya pada produk kesehatan. Selain itu dari responden yang melakukan pembelian impulsif di e-commerce juga untuk mengikuti tren terbaru dari produk kesehatan seperti misalnya masker. Biarpun adanya peraturan terkait PSBB, tidak membuat konsumen ketinggalan akan tren produk kesehatan karena dapat dengan mudah membelinya di $e$-commerce.

\section{KESIMPULAN}

Hasil dari penelitian ini, variabel perilaku hedonis berpengaruh signifikan terhadap impulse buying konsumen akan produk kesehatan di e-commerce. Variabel lainnya, yaitu promosi penjualan dan kualitas produk tidak memiliki pengaruh yang signifikan pada pembelian impulsif. Hal tersebut terjadi karena, perilaku hedonis cenderung memicu konsumen untuk melakukan pembelian tidak terencana. Terlebih di masa pandemi, konsumen melakukan pembelian impulsif karena, adanya rasa takut akan kenaikan harga dan akan virus yang dapat menyerang tubuh. Sehingga, konsumen yang memprioritaskan untuk melindungi tubuh dari virus dapat memicu pembelian impulsif pada produk kesehatan. Hasil dari riset ini dapat dipergunakan sebagai saran kepada pihak e-commerce Tokopedia, Bukalapak, dan Lazada. Menyediakan layanan yang baik dan menyediakan produk dengan kualitas yang baik bagi konsumen dapat memicu konsumen untuk memberikan penilaian yang baik juga sehingga, konsumen lain yang akan bertransaksi pada e-commerce tersebut tidak akan ragu untuk melakukan pembelian pada produk kesehatan tersebut. Pihak e-commerce juga bisa memicu pembelian yang dilakukan konsumen dengan memahami perilaku konsumen tersebut, dengan 
Irma Septiana \& Widyastuti Widyastuti. Pengaruh Sales Promotion, Product Quality, dan Hedonic Behavior pada Impulse Buying

menyediakan produk yang paling dicari konsumen dapat meningkatkan jumlah transaksi pada $e$ commerce tersebut.

Keterbatasan pada penelitian ini, dari jumlah e-commerce yang dibatasi, jumlah responden hanya 123 responden masih kurang untuk mengetahui keadaan yang sesungguhnya, serta pengisian angket biasanya tidak mencangkup pendapat sesungguhnya dari responden. Penelitian selanjutnya diharapkan bisa lebih menambah jumlah responden agar bisa lebih akurat dan dapat menambah atau melibatkan variabel lain seperti misalnya harga, merek, lifestyle, dan shopping emotion.

\section{DAFTAR PUSTAKA}

A.K, W., \& M.G.S, P. (2016). Impact of Sales Promotion on Consumer ' S Impulse Buying Behaviour ( Ibb ); Study in Supermarkets in Anuradhapura City. International Research Symposium Rajarata University of Sri Lanka, January, 321. https://doi.org/10.13140/RG.2.1.2963.1123

Akram, U., Hui, P., Kaleem Khan, M., Tanveer, Y., Mehmood, K., \& Ahmad, W. (2018). How website quality affects online impulse buying: Moderating effects of sales promotion and credit card use. Asia Pacific Journal of Marketing and Logistics, 30(1), 235-256. https://doi.org/10.1108/APJML-04-2017-0073

Angela, V., \& Paramita, E. L. (2020). Pengaruh Lifestyle dan Kualitas Produk terhadap Keputusan Impulse Buying Konsumen Shopee Generasi Z. Jurnal Ekobis : Ekonomi Bisnis \& Manajemen, 10(2), 248-262. https://doi.org/10.37932/j.e.v10i2.132

Anggreani, D. D. M., \& Suciarto A., S. (2020). Pengaruh Gaya Hidup Berbelanja dan Perilaku Hedonik terhadap Pembelian Impulsif (Studi) Pada Toko Belanja Online Shopee. Jemap, 3(1), 36-51. https://doi.org/10.24167/jemap.v3i1.2633

Beritasatu.com. (2020). Produk yang Diburu Selama Pandemi Covid-19. (https://www.beritasatu.com/DIGITAL/618695/KATEGORI-PRODUK-YANG-PALINGDIBURU-SELAMA-PANDEMI-COVID19, diakses pada 09 Januari 2021)

CNNIndonesia.com. (2020). Transaksi E-Commerce Naik Nyaris Dua Kali Lipat saat Pandemi. (https://www.cnnindonesia.com/ekonomi/20201021193353-92-561232/transaksi-e-commercenaik-nyaris-dua-kali-lipat-saat-pandemi, diakses pada 15 November 2020)

Covid19.co.id. (2020). Sistem E-Commerce Jadi Solusi Bagi Pelaku UMKM di Tengah Pandemi COVID-19. (https://covid19.go.id/p/berita/sistem-e-commerce-jadi-solusi-bagi-pelaku-umkmdi-tengah-pandemi-covid-19, diakses pada 15 November 2020)

Darma, L. A., \& Japarianto, E. (2014). Analisa Pengaruh Hedonic Shopping Value terhadap Impulse Buying dengan Shopping Lifestyle dan Positive Emotion sebagai Variabel Intervening pada Mall Ciputra World Surabaya. Jurnal Manajemen Pemasaran, 8(2), 80-89. https://doi.org/10.9744/pemasaran.8.2.80-89

Databoks.com. (2020a). Peningkatan Pengeluaran Rumah Tangga Akibat Pandemi Covid-19. (https://databoks.katadata.co.id/datapublish/2020/06/03/belanja-rumah-tangga-meningkatselama-pandemi-covid-19, diakses pada 31 Januari 2021)

Databoks.com. (2020b). Peta Persaingan E-commerce Indonesia pada Kuartal II-2020. (https://databoks.katadata.co.id/datapublish/2020/09/21/peta-persaingan-e-commerceindonesia-pada-kuartal-ii-2020, diakses pada 24 Januari 2021)

Hashmi, H. B. A., Shu, C., \& Haider, S. W. (2020). Moderating effect of hedonism on store 
environment-impulse buying nexus. International Journal of Retail and Distribution Management, 48(5), 465-483. https://doi.org/10.1108/JJRDM-09-2019-0312

Hikmah. (2020). Pengaruh Harga , Promosi dan Kualitas Produk terhadap Pembelian Impulsif di Kota Batam. Journal of Business and Economics Research (JBE), 1(2), 173-179.

Hultén, P., \& Vanyushyn, V. (2014). Promotion and shoppers' impulse purchases: The example of clothes. Journal of Consumer Marketing, 31(2), 94-102. https://doi.org/10.1108/JCM-06-20130603

Husnul, H. S., Bambang, I., \& Andi, S. R. (2017). The Impact of Product Quality, Promotion and Brand Image on Brand Loyalty and Impulse Buying Consumer Oriflame in Jember. International Journal of Business and Management Invention (IJBMI), 6(12), 1-5.

Indra Wiguna, A., \& Nurcaya, I. (2014). Pengaruh Fashion Involvement, Kualitas Produk dan Kewajaran Harga terhadap Impulse Buying. E-Jurnal Manajemen Universitas Udayana, 3(12), 247477.

Iprice.co.id. (2020). Peta E Commerce Indonesia. Retrieved from Peta E Commerce Indonesia. (https://iprice.co.id/insights/mapofecommerce/, diakses pada 15 November 2020)

Janie, D. N. A. (2012). Statistik Deskriptif dan Regresi Linear Berganda dengan SPSS. Semarang: Semarang University Press.

Jawapos.com. (2020). Berikut 5 Kategori Produk Paling Populer di Akhir Tahun. (https://www.jawapos.com/ekonomi/bisnis/28/12/2020/berikut-5-kategori-produk-onlinepaling-populer-di-akhir-tahun//, diakses pada 24 November 2020)

Kompas.com. (2020a). Mengenal impulsive buying, kebiasaan boros yang dapat direm saat pandemi. (https://www.kompas.com/tren/read/2020/05/27/181100765/mengenal-impulsive-buyingkebiasaan-boros-yang-dapat-direm-saat-pandemi?page=all, diakses pada 25 Januari 2021)

Kompas.com. (2020b). Pandemi Covid-19, apa saja dampak pada sektok ketenagakerjaan indonesia? (https://www.kompas.com/tren/read/2020/08/1 1/102500165/pandemi-covid-19-apa-sajadampak-pada-sektor-ketenagakerjaan-indonesia-?page=all, diakses pada 15 November 2020)

Kotler, Philip, dan A. (2004). Prinsip-prinsip Pemasaran (Kesepuluh). Jakarta: PT.bIndeks Gramedia.

Kurniawati, d \& restuti, S. (2014). Pengaruh Sales Promotion dan Store Atmosphere terhadap Shopping Emotion dan Impulse Buying pada Giant Pekanbaru. Jurnal Tepak Manajemen Bisnis, VI(3), 25. https://jtmb.ejournal.unri.ac.id/index.php/JTMB/article/view/2483

Lo, L. Y. S., Lin, S. W., \& Hsu, L. Y. (2016). Motivation for online impulse buying: A two-factor theory perspective. International Journal of Information Management, 36(5), 759-772. https://doi.org/10.1016/j.ijinfomgt.2016.04.012

Malhotra, N.K., \& Dash, S. (2016). Marketing Research an Applied Orientation (Ketujuh). Chennai: Pearson India Education Services.

Maulana, B. S. (2020). Pengaruh Kualitas Produk dan Harga terhadap Pembelian Impulsif serta Dampaknya pada Niat Beli Ulang ( Studi Empiris Pada Pengguna Shoope . co . id di Kota Surakarta ). Jurnal Manajemen dan Bisnis. 5(1), 86045.

Mowen, J. \& Minor, M. (2002). Perilaku Konsumen (Kelima). Jakarta: Erlangga. 
Irma Septiana \& Widyastuti Widyastuti. Pengaruh Sales Promotion, Product Quality, dan Hedonic Behavior pada Impulse Buying

Naeem, M. (2020). Understanding the customer psychology of impulse buying during COVID-19 pandemic: implications for retailers. International Journal of Retail and Distribution Management, 49(3), 377-393. https://doi.org/10.1108/IJRDM-08-2020-0317

Peraturan.bpk.go.id. (2020). Pembatasan Sosial Berskala Besar dalam Rangka Percepatan Penanganan Corona Virus Disease 2019 (COVID-19). (https://peraturan.bpk.go.id/Home/Details/135059/pp-no-21-tahun-2020, diakses pada 15 Maret 2021)

Peter, J. P. and J. C. O. (2014). Perilaku Konsumen dan Strategi Pemasaran Terjemahan oleh Diah Tantri Dwiandani (Kesembilan). Jakarta: Erlangga.

Ramdhani, N. (2012). Adaptasi Bahasa dan Budaya Inventori Big Five. Placenta, 18(2-3), 181-188. https://doi.org/10.1016/S0143-4004(97)90091-6

Salam, Burhanuddin. (1997). Logika Materiil Filsafat Ilmu Pengetahuan. Jakarta: Rineka Cipta

Solomon, M.C., Marshall. G.W., and Stuart, E. (2008). Marketing Real People Real Choices. New Jersey: Pearson Prentice Hall.

Sri, W., \& Asnawati. (2018). the Influence of Hedonic Shopping Motivation to the Impulse Buying. Rjoas, 2(February), 99-107.

Sujianto, A. E. (2009). Aplikasi Statistik dengan SPSS 16.0. Jakarta: Prestasi Pustaka.

Tamilselvi, J. (2019). Impact of Sale Promotion Technques on Consumers Impulse Buying Behaviour towards Apparels at Bangalore. Asian Journal of Management Sciences \& Education, 4(March), 116-124.

Tjiptono, F. dan Chandra, G. (2012). Pemasaran Strategik (Kedua). Yogyakarta: Penerbit Andi.

Widagdo, B., \& Roz, K. (2021). Hedonic Shopping Motivation and Impulse Buying: the Effect of Website Quality on Customer Satisfaction. Journal of Asian Finance, Economics and Business, 8(1), 395-405. https://doi.org/10.13106/jafeb.2021.vol8.no1.395

Wikipedia.com. (2020). Perdagangan Elektronik. (https://id.wikipedia.org/wiki/Perdagangan_elektronik\#: :text=Perdagangan\%2520elektronik\% 25, diakses pada 15 Januari 2021)

Xu, Y., \& Huang, J. S. (2014). Effects of price discounts and bonus packs on online impulse buying. Social Behavior and Personality, 42(8), 1293-1302. https://doi.org/10.2224/sbp.2014.42.8.1293

Yeboah, A., \& Owusu-Prempeh, V. (2017). Exploring the Consumer Impulse Buying Behaviour from a Range of Consumer and Product Related Factors. International Journal of Marketing Studies, 9(2), 146. https://doi.org/10.5539/ijms.v9n2p146

Yiğit, M. K. (2020). Consumer mindfulness and impulse buying behavior: Testing moderator effects of hedonic shopping value and mood. Innovative Marketing, 16(4), 24-36. https://doi.org/10.21511/im.16(4).2020.03

Zahara, R. (2019). Pengaruh sales promotion terhadap impulse buying konsumen. Jurnal Manajemen Strategi dan Aplikasi Bisnis, 2(1), 39-44. https://doi.org/10.36407/jmsab.v2i1.46 